\title{
The recommendations of the De Kock Commission of Inquiry and its implications for foreign security investments by South African residents
}

\author{
N. Bhana \\ Graduate School of Business, University of Durban-Westville, Durban
}

South African investors have been precluded from investing in foreign securities by the Exchange Control Regulations of 1961 . Furthermore, the monetary policy pursued by the authorities has resulted in an inefficient financial market. Investments on the capital market have not earned satisfactory real rates of return, and prices on the JSE appear to have been driven to artificial heights. The De Kock Commission of Inquiry has proposed several recommendations which will have far-reaching consequences for investors in South Africa. The proposal of market-related interest rates and the abolition of prescribed investments by institutional investors is likely to result in long-term securities earning substantially higher real rates of return. The relaxation of exchange control for both direct and portfolio investment is likely to stem the flow of funds into the JSE. Investment funds can be expected to flow between the JSE and the various foreign equity markets depending on the economic prospects in the different countries. The high foreign exchange cost and poor liquidity of the local exchange market has been an obstacle to investors in foreign securities. The creation of a larger and more efficient foreign exchange market is likely to facilitate international portfolio diversification in South Africa.

S. Afr. J. Bus. Mgmt. 1985, 16: $204-208$

Suid-Afrikaanse beleggers is in terme van die Wisselkoers Beheer Regulasies van 1961 verhinder om in buitelandse effekte te belê. Boonop het die monetêre beleid van die regering gelei tot 'n oneffektiewe finansiële mark. Beleggings op die kapitaalmark het geensins bevredigende reële opbrengste gelewer nie en pryse op die Johannesburgse Effektebeurs (JEB) het kunsmatige hoë vlakke bereik. Die De Kock Kommissie van Ondersoek het verskeie aanbevelings gemaak wat verreikende gevolge vir die belegger in Suid-Afrika sal hê. Die voorstel van markgerigte rentekoerse en die afskaffing van voorgeskrewe beleggings van institusionele beleggers sal bes moontlik lei tot langtermyn effekte met aansienlike hoër vlakke van reële opbrengste. Die verslapping van wisselkoersbeheer op beide direkte en portefeulje beleggings mag moontlik die vloei van fondse na die JEB stuit. Afhangende van die ekonomiese vooruitsigte van die verskiliende lande, kan verwag word dat beleggingsfondse sal vloei tussen die JEB en die verskillende buitelandse aandelemarkte. Die hoë buitelandse wisselkoerskoste en die swak likwiditeit van die plaaslike mark is natuurlik 'n probleem vir beleggers in buitelandse effekte. Die skepping van 'n groter en meer doeltreffende buitelandse aandelemark sal bydra tot die skepping van internasionale portefeulje-diversifikasie in Suid-Afrika.

S.-Afr. Tydskr. BedryfsI. 1985, 16: $204-208$

\section{N. Bhana}

Graduate School of Business, University of Durban-Westville, Durban, $\mathbf{4 0 0 0}$ Republic of South Africa

\section{Introduction}

In 1977 the South African government appointed a Commission of Inquiry to enquire into the monetary system and monetary policy in South Africa. The reasons for the Commission's appointment were to investigate the major changes that had occurred in the role of gold, the volatility of the international exchange rate system, and certain problems besetting South Africa's financial markets. These developments contributed to a combination of inflation, recession, and balance of payments disequilibrium that has been experienced in South Africa in recent years. Because of the great distance of South Africa from its major trading partners in the developed countries, the financial markets in South Africa were relatively inactive and inefficient. Furthermore, the monetary policy adopted by the authorities in the past had, to a large extent, prevented the financial markets from developing into being free and competitive markets. During May 1985 the De Kock Commission (1985) published its final report on the monetary system and monetary policy. The Commission was guided by the principle that financial markets will function best in the national interest if they are reasonably free and competitive, and if they produce realistic, market-related interest rates. It is submitted that the Commission's recommendations are likely to influence the flow of funds between the capital market and the JSE, and investment funds are also likely to be chanelled into foreign securities, enabling domestic investors to improve portfolio performances.

\section{Exchange rate policy in South Africa}

The purchase of a foreign security requires the purchase of the currency in which the security is denominated. The currency transactions take place in foreign exchange markets, and this adds to the risk of investing in foreign securities. The foreign exchange market can be divided into two distinct categories. In the 'spot' market, foreign exchange transactions are traded currently or on the spot. An investor can also protect the investment against exchange rate fluctuations by the use of 'forward' or futures cover. In the futures market, an investor can deal in futures contracts for the exchange of one currency for another at a specific future date and at a specific exchange ratio. Prindl (1976) showed that most operators in international financial markets use foreign exchange hedging as a means of reducing the risk arising from currency fluctuations. Therefore, an efficient foreign exchange market is necessary to protect investors against currency risk associated with foreign securities.

South Africa's long-term exchange rate policy has been 
shaped by the Exchange Control Regulations of 1961, as amended. Goedhuys (1982:174-176) showed that an important feature of South Africa's exchange rate policy is the official control exercised by the Reserve Bank over all foreign exchange transactions. All foreign exchange receipts must be sold to authorized dealers within seven days, and all foreign exchange requirements must be purchased from them in accordance with imports and other transfers for which prior permission is required from the Reserve Bank. The De Kock Commission's interim report (1978) identified several deficiencies in the foreign exchange policy in South Africa. The basic weakness was the absence of an active and competitive foreign exchange market in South Africa. The Reserve Bank not only determined the rand-dollar exchange rate but also prescribed the buying and selling rates at which banking institutions had to deal with their clients. Therefore, the foreign exchange market in South Africa was subject to a form of price control by the Reserve Bank. In 1977 the South African government appointed the De Kock Commission of Inquiry to investigate three broad areas, namely: the money market, the foreign exchange markets, and the monetary policy.

The De Kock Commission's (1978) investigation revealed several deficiencies in the foreign exchange policy in South Africa. Firstly, in the absence of an active and competitive spot foreign exchange market, the Reserve Bank had no choice but to peg the rand either to a single currency or a basket of currencies. The De Kock Commission (1978:14) stated that the rand-dollar peg was changed very infrequently. However, this did not provide any exchange rate stability in that there were times when the rand was forced to float with the United States dollar in terms of other currencies in directions determined by the strength or weakness of the dollar. A major defect of the fixed rand-dollar pegged exchange rate system was that changes in South Africa's balance of payments position was immediately reflected in the level of foreign reserves held by the Reserve Bank, and not in the official exchange rate.

The De Kock Commission (1978:15) also cited the deficiency in the spot foreign exchange market arising from the artificially high spreads between buying and selling rates charged by authorized currency dealers in South Africa. It was shown that by international standards these spreads were relatively large, and resulted in substantial profits for authorized foreign exchange dealers in South Africa. The relatively wide and fixed spreads rendered the foreign exchange market in South Africa inefficient. It resulted in increased costs for both buyers and sellers of foreign exchange and thereby decreased the attractiveness of dealing in foreign transactions. Additionally, the wide margins also had the effect of diverting foreign exchange dealings, involving large transactions to overseas exchange markets where narrower margins prevailed.

Besides the shortcomings of the spot foreign exchange market, the De Kock Commission (1978:15) also found serious weakness in the forward exchange market. Prior to 1979 forward buyers as well as forward sellers of foreign currency were subject to a $1 \%$ premium above the prevailing spot rate. The forward exchange rate was artificial in that it bore no relationship to the interest rate differentials between the different countries, and was unrelated to the demand and supply factors. Furthermore, forward cover was available only for transactions involving goods and related services. Forward cover was unavailable to the private sector for transactions such as loan repayments, interest, royalties, dividends, and capital invested in foreign securities. Thus, portfolio managers were precluded from obtaining forward cover on the repatriation of their foreign investments, and this increased the risk of investing in foreign securities. This, in conjunction with exchange control, has largely contributed to the absence of foreign securities in the portfolios of most South African investors.

An essential part of both the long-term and short-term recommendations of the De Kock Commission (1978) was the need to develop a more active and competitive spot and forward foreign exchange market in South Africa. From January 1979, the Reserve Bank started to quote exchange rates for the rand on a daily basis. The Financial Mail (1982a;751) reported that changes in the exchange rates become more frequent and smaller, and the general trend of the rand seems to be following the country's underlying economic fundamentals quite closely. Under the new system that emerged following the first interim report of the De Kock Commission, the forward rate began to reflect to some extent the differential between the United States interest rates and those in South Africa. However, the Reserve Bank continued to market the country's gold output, which constitutes about $50 \%$ of the country's foreign exchange earnings, and continued to pay the mining houses in rands. The Reserve Bank thus continued to exercise a dominating influence on the foreign exchange market in South Africa. Furthermore, the lack of integration between the spot and forward markets precluded the attainment of market-determined exchange rates in South Africa.

On 7 February 1983, Horwood (1983a) announced that the South African Reserve Bank had abolished exchange control over non-residents. With it disappeared the financial rand and the dual exchange rate system as it existed in one form or another since exchange control over non-residents was first introduced in South Africa in 1961. Foreign investors were now free to invest or withdraw funds from South Africa, either of a direct or of a portfolio investment nature, without obtaining prior approval from the Reserve Bank. As in the past, all current income earned on such investments was freely transferable from the country. The Horwood (1983a) announcement was important in that it resulted in the partial freeing of the financial markets, although it still left a major part of the exchange control intact. Although there were major concessions on tourist and business allowances, the main exchange control over residents was retained.

During August 1983, Horwood (1983b) made an important announcement regarding the further development of the foreign exchange market in South Africa. It was stated that the intention to improve the technical functioning of the foreign exchange market was a necessary prelude to further relaxation of exchange controls. It was announced that from 5 September 1983, the Reserve Bank will pay South African gold mines in dollars instead of rands for gold supplied to it. Like any other exporter, the mines will be required to sell the dollar earnings to authorized foreign exchange dealers. It was further announced that the Reserve Bank will no longer quote a spot exchange rate but will influence the exchange rate by intervention in the foreign exchange market. Horwood (1983b) also made sevęral announcements to encourage the development of an efficient foreign exchange market in South Africa. Firstly, it was announced that the forward exchange cover provided by the Reserve Bank to authorized exchange dealers will be phased out over a period of three years, falling away on 31 August 1986. Secondly, any banking institution which sells forward cover to its clients will be required to buy the required currency in the spot market. In this way forward 
exchange transactions will influence the spot exchange rates and the two markets will be effectively integrated.

It has been shown above that the monetary authorities' attempts to create a market-related foreign exchange market in South Africa is being realized. Institutional limitations appear to have prevented a more efficient market for foreign exchange in South Africa. Semadeni (1984:94) showed that a major shortcoming of the local exchange market is that it is very small in terms of international standards, and that the rand is traded on a limited basis internationally. Additionally, the local foreign exchange markets operate during office hours only and this adds to the liquidity problems. Goedhuys (1982) demonstrated that the Reserve Bank deals with authorized dealers in dollars only. Thus, the dealers are required to approach overseas markets to convert dollars into other foreign currencies. The great distance of South Africa from all other major foreign exchange markets results in local dealers facing high operating cost on relatively small turnover. Thus, the spread between buying and selling rates for nondollars is much higher than that for United States dollars. Operators in the foreign exchange market are thus paying much higher transaction costs than those in the developed countries. The higher foreign exchange costs and the poor liquidity of the exchange market has been a major obstacle for investors in foreign securities. The creation of a larger and more efficient market for foreign exchange could facilitate international portfolio diversification in South Africa.

\section{Exchange control and foreign investments by South African residents}

The Exchange Control Regulations of 1961, as amended, preclude South African residents from acquiring foreign securities from income derived in South Africa. Any person or institution resident in South Africa will have to make application to the South African Reserve Bank for permission to acquire foreign securities. As a rule exchange control permission is only granted to resident South African companies when making 'direct' investment where some form of control is obtained over the foreign company concerned. In recent years the Reserve Bank has been very favourably disposed towards foreign investments by South African companies which are of strategic importance to the country (i.e. where it promotes imports, exports, or where it strengthened South Africa's international business status). The usual requirement for approving such direct investments is that the South African investor finances the acquisition from borrowed funds so as to minimize any possible drain on the country's foreign reserves. The present exchange control regulations prohibit investments by South African residents in foreign non-direct or portfolio investments. However, several large South African companies and institutional investors have accumulated large portfolios of foreign securities out of foreign earnings. Nevertheless, the holding of foreign securities in South Africa is very small in comparison with that of the developed countries (which are not constrained by exchange control restrictions).

During May 1985, the De Kock Commission released the final report of their intensive study of the monetary system and monetary policy in South Africa. In line with the basic philosophy of the two interim reports, the final report reemphasizes the need to establish a market-related monetary policy in South Africa. The Commission sketched the progress towards abolishing exchange controls arising from the recommendation in the interim reports, namely, the relaxation of exchange control over non-residents. The De Kock Com- mission's (1985) final report recommended that the remaining exchange controls over residents be substantially relaxed and simplified. However, the alternative of completely abolishing exchange controls was not recommended. It has been suggested that the recommended approach would ultimately lead to either the complete phasing out of exchange controls or the retention of a limited set of precautionary controls. The De Kock Commission (1985:133) gave the following motivation for further relaxation of exchange controls in South Africa:

'In reaching this decision the Commission took special cognisance of the political uncertainties in South Africa. It was also influenced by the realisation that it will still take some time for an active, competitive and generally efficient forward exchange market to develop in South Africa. In these circumstances it was judged that the complete abolition of all remaining exchange control at this stage might produce unacceptable, even though temporary, disruption in the form of some combination of undue downward pressure on the reserves and/or the exchange rate, undue upward pressure on interest rates, and declines in share prices and real estate values'.

The De Kock Commission (1985:134) recommended that the existing liberal application of exchange control relaxation in respect of direct investments by resident South Africans in foreign companies be further relaxed so that such acquisitions become automatic, provided they meet the established criteria. This recommendation appears to be a major breakthrough for companies such as Barlow Rand Limited, Anglo American Corporation,, Liberty Life, etc. which are actively involved in take-overs of overseas companies. Under the existing exchange control regulations these companies require approval from exchange control authorities before a take-over deal can be finalized. As secrecy and time are of essence in take-over negotiations, the existing exchange control regulations appear to prejudice South African companies desirous of making direct investment in foreign companies. If the Commission's recommendation in this regard is accepted, approval will become a formality and this will greatly facilitate foreign take-overs.

The De Kock Commission (1985:134) also recommended a progressive relaxation of exchange control over foreign portfolio investments. The Commission recommended that initially, registered insurers, pension funds, and mutual funds be allowed to invest $10 \%$ of their annual cash inflows in securities approved by the Registrar of Financial Institutions. The De Kock Commission (1985) also recommended that in due course such provisions should be extended to financial institutions and corporate bodies such as mining houses. The Commission also recommended that eventually the prohibition on foreign portfolio investments be extended to individuals and non-corporate bodies. This could be accomplished, for instance, by allowing each individual to make annual foreign investments up to a certain amount, without approval. The De Kock Commission did not specify any time period but suggested that the state of both the balance of payment and the domestic economy must be conducive to implement these relaxations.

The De Kock Commission (1985) also investigated the prescribed investment requirements of institutional investors in South Africa. In terms of this requirement, institutional investors are required to invest a certain percentage of their assets in Government Stock and other gilt-edged securities. These compulsory investments create a captive market for public sector borrowing at rates of interest that frequently, 
and especially in times of inflation, have not resulted in a 'real' return. This subsidization of public sector borrowing is effectively borne by beneficiaries of insurance policies and pension rights. Furthermore, prescribed investments also cause a lack of investment flexibility in that institutional investors have little say regarding the amount and the timing of funds to be invested in prescribed investments. Prescribed investments distort the allocation of scarce resources in the sense that the public sector is subsidized at the expense of other market participants.

The De Kock Commission (1985:19) recommended that the prescribed investment regulations be withdrawn at some future date. The Commission reported that these regulations have had harmful economic consequences, and they are no longer necessary either to ensure the solvency of the institutions or to finance public sector spending. The institutional investors have long argued that South Africa's long-term interest rates have been artificially low owing to the prescribed assets requirements and exchange control regulations. In particular it has been argued that long-term rates in South Africa's capital markets have not provided satisfactory real rates of return to investors. This is unsatisfactory, considering that real rates of return on long-term funds in the developed countries are currently averaging 5\%. Nevertheless, institutional investors are obliged to divert funds into prescribed investments despite the availability of more attractive investments. The eventual removal of these constraints should therefore have the effect of raising yields on long-term securities to more competitive levels, moving closely in line with yields prevailing in the developed countries.

It is submitted that these measures are likely to have serious consequences for the investment market in South Africa. During recent years, the main attraction of the JSE has been the unsatisfactory real rates of return prevailing in the capital market. Satisfactory real rates of return on capital market securities are likely to divert funds away from the JSE. The low yields on most 'blue chip' equities is likely to assist in this trend. It is suggested that investors and institutional investors in particular are likely to give greater consideration to investing in the capital markets in view of the satisfactory risk-return characteristics it would offer. The development of the capital market in turn is likely to lead to a better allocation of funds in the South African economy. It is submitted that the additional flow of funds into the capital markets will be more conducive to economic growth than the current 'paper chase' on the JSE.

The De Kock Commission's (1985) recommendations relating to the relaxation of exchange controls for South African residents are a recognition that the existing measures are inefficient in rationing available foreign exchange among various domestic users. The Commission is of the opinion that market forces are more likely to allocate foreign exchange efficiently. Furthermore, the recommendations of the Commission are merely the first step towards the ultimate system in which foreign exchange allocation is left entirely to market forces. Nevertheless, it is submitted that the Commission's recommendations are likely to have far-reaching implications for South African citizens. The financial media in South Africa has reacted favourably to the proposed exchange control relaxations. Ryan (1985) reported that most major insurance companies have indicated a desire to invest in foreign securities when the recommendations of the De Kock Commission becomes law. It was also reported that the annual cash inflow of the institutional investors is currently nine billion rands, therefore, there is a potential to invest up to 900 million rands in foreign securities. It is expected that institutional investors will seek foreign securities to improve the risk-return characteristics of their portfolios. However, it is unlikely that the institutional investors will immediately make large investments in foreign securities as they do not have sufficient knowledge of foreign securities markets, and it will take some time to build up suitable expertise.

It is submitted that the proposed relaxations of exchange control for South African residents is likely to create a more efficient market for equities in South Africa. The existing exchange controls have forced the institutional investors to invest in local equities. Various market observers such as the Financial Mail (1982b:1018) have commented on the 'weight of institutional funds' argument which states that given the restricted size of the local equity market and the enormous cash flows of the institutional investors seeking investment opportunities, there is a tendency for share prices on the JSE rising to artificial levels. The Financial Mail (1984) also indicated that there is a shortage of 'blue chip' and other categories of shares sought by the institutional investors, resulting in a limited marketability of better quality shares traded. It was also shown that the turnover of shares on the JSE, as a percentage of market capitalization, was only $6 \%$ in 1982. The corresponding figures for the United States and the United Kingdom were 35 and $34 \%$ respectively. It is submitted that the limited marketability of better quality shares has contributed further towards the artificial equity prices on the JSE.

The 'weight of institutional funds' argument is not strictly valid in that artificially high prices cannot be maintained in the long-term; there are periods when major downward corrections take place (such as those witnessed in 1969 and 1976). Nevertheless, the weight of institutional funds is likely to contribute to artificial equity prices in the short-term. The recommendations of the De Kock Commission (1985) are likely to have some impact on JSE prices. It is reasonable to expect that institutional investors with their large portfolios would take advantage of the opportunity to invest in foreign securities. This will enable them to attain balanced portfolios, increase return and reduce portfolio risk, and possibly benefit from currency hedging. The outflow of institutional funds into foreign securities will to some extent stem the flow of funds into the JSE and consequently remove the artificial level of prices prevailing here.

The De Kock Commission (1985:132) also revealed that exchange control has at times contributed to inflation and general economic instability. It cited the $1979-83$ period during which the gold boom and the balance of payment surplus contributed towards a 'bottling up' of funds in the South African economy, and excessive rise in the money supply, and artificially low levels of real interest rates resulted in a further flow of funds into the JSE and the subsequent rise in equity prices. The De Kock Commission (1985:133) showed that during periods when the balance of payments position is in a surplus, a net capital outflow (such as investment in foreign securities) may be desirable in order to prevent an undue appreciation in exchange rate or excessive rise in money supply. Alternatively, when the balance of payment is in deficit, a capital inflow attracted by high interest rates and realistic exchange rates, may be beneficial to South African investors. Exchange controls have thus indirectly stimulated equity values on the JSE. The De Kock Commission (1985:3) recognized the various distortions in the interest rates which undermine the efficient working of the financial markets. Therefore, it makes several recommendations leading 
to the attainment of realistic and market-related interest rates in the South African financial markets.

It is submitted that the various recommendations of the De Kock Commission (1985), when implemented by the authorities, will go a long way towards creating an efficient financial market. These recommendations are likely to have far-reaching implications for local investors. Firstly, the attainment of market-related interest rates will result in a more efficient flow of funds between the equity market and the capital market, investment funds flowing into the JSE when the interest rates are low, and vice versa when interest rates are high. Secondly, the relaxation in prescribed investments by institutional investors is likely to contribute towards marketrelated interest rates for government and gilt-edged securities, and this in return will facilitate the greater mobility of funds between capital market securities and the equity market. Thirdly, the partial relaxation of exchange control relating to portfolio and non-direct foreign investment will create a more efficient equity market in South Africa. Equity prices on the JSE will properly reflect the underlying fundamentals of the South African economy. Depending on the state of the economy and prospects for listed companies, investment funds can be expected to move between the JSE and the various foreign equity markets. This will enable South African investors to reap the benefits of international portfolio diversification.

The South African authorities have already set in motion the implementation of the first and second interim reports of the De Kock Commission of Inquiry. The State President and various leading government officials have approved in principle the final report of the De Kock Commission. It would seem that South Africa is well on the road towards a basically market-related economy, with minimal government interference in the market mechanism. The De Kock Commission (1985) did not completely abolish exchange control, though it provided the basic guidelines which will ultimately lead to a system where foreign exchange allocation is left entirely to market forces. A gradual process of dismantling exchange control for residents is appropriate in view of the limited holding of foreign exchange reserves by the Reserve Bank and the possible short-term disruptive effects of a complete abolition. The most opportune moment for phasing out exchange control would be a favourable economic climate which would include a healthy surplus on the balance of payments account and a strong exchange rate value of the rand. Such favourable economic events are most likely to prevail when the price of gold is higher. It is therefore submitted that the authorities should institute an orderly process of abolishing exchange controls in line with the strengthening of the domestic economy.

\section{Conclusion}

The foreign exchange market is somewhat inefficient because of the prevailing institutional and environmental limitations. The interim report of the De Kock Commission showed that the basic weakness of the exchange rate policy was the absence of an active and competitive foreign exchange market in South
Africa. The main recommendations of the interim report have been implemented and the monetary authorities have come a long way towards the creation of a market-related foreign exchange market in South Africa. However, a major shorcoming of the local exchange market is that it is small by international standards, and the rand is not traded internationally on a large scale. To date the high cost of foreign exchange transactions and poor liquidity of the exchange market has been an obstacle to investors in foreign securities. The authorities should devote further attention to the creation of a larger and more efficient foreign exchange market as this will facilitate international portfolio diversification by South African investors.

The recommendations of the De Kock Commission of Inquiry are likely to have major consequences for the financial and equity markets in South Africa. The ultimate objective is that financial markets should produce realistic marketrelated interest rates. This is likely to result in substantially improved yields on long-term securities. The existing exchange control regulations and the low yields on long-term securities have resulted in a large flow of funds into the JSE and artificially high short-term equity prices. The relaxation of exchange control and market-related yields on the capital markets are likely to stem the flow of funds into the JSE. Investment funds can be expected to flow between the JSE and various foreign equity markets depending on the economic prospects in the different countries. By investing in foreign securities, South African investors may benefit from the high rates of growth experienced in certain countries. However, it is unlikely that institutional investors will immediately make large foreign investments as they may not have the necessary financial expertise.

\section{References}

De Kock Commission. 1978. The Commission of Inquiry into the Monetary System and Monetary Policy in South Africa: Exchange Rates in South Africa. Interim Report, RP112/1978. Pretoria: Government Printer.

De Kock Commission. 1985. The Commission of Inquiry into the Monetary Systems and Monetary Policy in South Africa. Final Report, RP70/1984. Pretoria: Government Printer.

Exchange Controls - Go for freedom. 1982a. Financ. Mail, vol.86, (7) November 12, 751.

Institutional cash - Get off our backs Owen. 1982b. Financ. Mail, vol.86, (9), November 26, 1016-1018.

Expanding the Empires. 1984. Financ. Mail, vol.92, (3) May 4, $297-304$.

Goedhuys, D.W. 1982. Money and Banking. 2nd Edition. Johannesburg: McGraw-Hill Book Company, $275 \mathrm{p}$.

Horwood, O.P.F. 1983a. Statement on the abolition of exchange control over non-residents. S. Afr. Reserve Bank $Q$. Bull., (147), March, 25-27.

Horwood, O.P.F. 1983b. Statement with regard to the further development of the foreign exchange market in South Africa. $S$. Afr. Reserve Bank $Q$. Bull., (149), September, 21-22.

Prindl, A.R. 1976. Guidelines for MNC Money Managers. Harv. Bus. Rev., January - February, 73-80.

Ryan, C. 1985. Institutions will jump at of fshore chance. Sunday Times - Business Times, June 23, 1 .

Semadeni, A. 1984. Hedging against currency risk. Financ. Mail, vol.94, (9), November 30,94 . 